\title{
PERSONALITY TO RESILIENCE: A SYSTEMATIC REVIEW
}

\author{
Dewi Sri Mustikasari \\ Universitas Muhammadiyah Malang \\ tikadewisri@gmail.com
}

\begin{abstract}
ABSTRAK: Resiliensi merupakan sebuah kemampuan seseorang untuk beradaptasi dan bertahan, serta tetap teguh dalam kondisi yang sulit. Resiliensi dapat memberikan dampak yang baik yaitu menurunkan kecemasan dan membuat hidup menjadi lebih bahagia. Resiliensi dipengaruhi oleh faktor personality yang melekat pada diri seseorang. Personality menjadi sebuah faktor proteksi dalam perkembangan resiliensi itu sendiri. Personality diukur menggunakan Big Five Personality Model. Faktor-faktor penyusun kepribadian model ini yaitu extraversion, neuroticism, openess, agreeableness, dan conscientiousness. Review ini bertujuan untuk untuk memberikan gambaran mengenai hubungan personality dan resiliensi dari 10 jurnal yang dipublikasikan dalam jurnal international mulai tahun 2014-2018.
\end{abstract}

Kata kunci: kepribadian; resiliensi

ABSTRACT: Resilience is a person's ability to adapt and survive, and remain firm in difficult conditions. Resilience can have a good impact which is reducing anxiety and making life happier. Resilience is influenced by personality factors inherent in a person. Personality is a protection factor in the development of resilience itself. Personality is measured using the Big Five Personality Model. The factors that build personality of this model are extraversion, neuroticism, openess, agreeableness, and conscientiousness. This review aims to provide an overview of the relationship of personality and resilience of 10 journals that was published in international journals from 2014-2018.

Key word: personality; resilience

\section{PENDAHULUAN}

$$
\text { Resiliensi didefinisikan sebagai }
$$

kemampuan untuk mengatasi stressor

internal maupun eksternal yang dialami

seseorang (Conor \& Davidson, 2003).

Setiap orang akan selalu dihadapkan

dengan berbagai stressor dalam hidupnya

dan tidak menutup kemungkinan muncul

masa-masa sulit yang membuatnya harus

bisa bertahan hidup. Atribut dari resiliensi terdiri atas "strategi positif coping untuk

mengatasi stres (seperti secara aktif

mencari permasalahan, mencari jalan

alternatif untuk mengelompokkan stres),

sebuah kemampuan untuk beradaptasi

terhadap lingkungan yang membuat stres,

dan kemampuan untuk menjaga kesehatan

mental dan fisik selama periode stres

berlangsung (Leon \& Halbesleben, 2014). 
Resiliensi merupakan sebuah seseorang ini menuntutnya dapat bertahan kemampuan seseorang untuk beradaptasi dan melewati dengan baik, jika tidak akan dan bertahan, serta tetap teguh dalam menimbulkan beberapa permasalahan lain. kondisi yang sulit (Reivich \& Shatte, Hal ini juga dapat menyebabkan resiko 2002). Seseorang yang resilien akan berkembangnya gangguan mental seperti berusaha untuk meregulasi emosinya, depresi, kecemasan, dan posttraumatic berusaha agar tetap tenang walau berada di disorders (Davydov, Stewart, \& Chaudieu, bawah tekanan (Reivich \& Shatte, 2002; 2010). Sebuah studi menunjukkan bahwa Bluth, Campo, Futch, \& Gaylord, 2016) seseorang yang resilien dapat menjaga atau kemudian mengeskpresikan emosinya memulihkan kesehatan fisik dan secara tepat. Semua orang dapat psikologisnya melalui penurunan melakukan resiliensi, meskipun resiliensi konsekuensi-konsekuensi negatif yang ini terjadi tidak secara otomatis dan stabil, didapatkan dari masa sulitnya (Conor $\&$ tetapi resiliensi merupakan kombinasi yang kompleks dari berbagai faktor yang terdapat pada kesulitan dan kondisi situasi saat kesulitan itu terjadi (Buikstra, et al., 2010).

Dalam kehidupan sehari-hari setiap orang tidak akan pernah lepas dari permasalahan, stressor atau bahkan mendapat pengalaman hidup yang buruk. Beberapa menjadi masa-masa sulit bagi seseorang. Pengalaman-pengalaman buruk Davidson, 2003).

Resiliensi ini merupakan sebuah proses yang menunjukkan adaptasi seseorang secara positif dari stres atau pengalaman traumatiknya (Sills, Cohan, \& Stein, 2006). Maka dari itu resiliensi ini sangat bermanfaat untuk kesehatan mental seseorang. Semakin resilien seseorang maka semakin baik juga seseorang mengurangi faktor-faktor resiko yang dapat menganggu mentalnya (Davydov, 
Stewart, \& Chaudieu, 2010). Beberapa faktor yang dapat membentuk seseorang untuk menjadi resilien yaitu kompetensi personal, mempercayai insting dan toleransi terhadap afek negatif, penerimaan positif terhadap perubahan, kontrol, dan pengaruh spiritual (Conor \& Davidson, 2003). Kemampuan ini tidak hanya akan terjadi pada orang dewasa saja, tetapi juga bisa terjadi pada anak-anak. Dalam review ini akan dibahas dalam berbagai karakteristik subjek termasuk kategori usia anak-anak.

Salah satu manfaat dari resiliensi adalah dapat menurunkan kecemasan (Shi, Liu, Wang, \& Wang, 2015). Selain itu, resiliensi mempengaruhi afek positif dan mengurangi afek negatif, sehingga membuat seseorang menjadi lebih bahagia (Lü, Wang, Liu, \& Zhang, 2014). Resiliensi juga dapat membantu meningkatkan kepuasan hidup (Liu, Wang, Zhou, \& Li, 2014) untuk itulah seseorang dapat memiliki harapan untuk mencapai subjective well-being dalam hidupnya (Satici, 2016).

Setiap orang memiliki cara sendiri untuk menjadi resilien terhadap kesulitannya. Kemampuan seseorang untuk menjadi resilien ini juga terkait dengan kepribadian atau personality yang melekat pada orang tersebut. Ada banyak teori yang menjelaskan kepribadian seseorang terbentuk. Salah satunya teori yang disampaikan oleh Robert McCrae dan Paul Costa yaitu big five factors (sering ditulis big five personality). Faktor-faktor penyusun kepribadian model ini yaitu extraversion, neuroticism, openess, agreeableness, dan conscientiousness (Costa \& McCrae, 1992).

Dalam bukunya Schultz \& Schultz (2009) mendeskripsikan masing-masing faktor tersesbut, seperti neuroticism ini mempunyai ciri seseorang yang mudah cemas, merasa tidak aman, mudah merasa tegang dan gugup. Extraversion mempunyai ciri-ciri yaitu mudah 
bersosialisasi, banyak bicara, ceria dan hangat, dan penuh kasih sayang. Openess dideskripsikan dengan orisinal, tidak tergantung, kreatif, dan berani. Agreeableness dideskripsikan sebagai seseorang yang baik hati, berhati lembut, dapat dipercaya, dan sopan. Sedangkan conscienstiousness dideskripsi-kan sebagai seseorang yang memiliki sifat peduli, dapat diandalkan, pekerja keras, dan terorganisasi.

Beberapa studi berusaha meneliti keterkaitan antara kepribadian yang mengacu pada teori big five personality ini terhadap resiliensi. Pembahasan mengenai kepribadian dan resiliensi ini masih menjadi pembahasan yang menarik hingga saat ini. Beberapa studi tak lagi menggunakan satu kesatuan model lima faktor, tetapi sudah menggunakan salah satu faktor tertentu untuk dikaitkan dengan resiliensi, seperti penelitian yang dilakukan oleh Jie \& Du (2015).
Kepribadian dapat menentukan sikap seseorang ketika kesulitan datang, seperti memiliki kemampuan untuk membuat humor; menjadi lebih bertanggung jawab kepada kehidupan sosialnya; lebih mudah beradaptasi dan memiliki toleransi; memiliki self-esteem, self-dicipline dan self-control yang baik, memilki rencana-rencana, penyelesaian masalah, dan kemampuan berpikir kritis (Garcia \& Mendieta, 2014).

Kepribadian menjadi sebuah faktor proteksi dalam perkembangan resiliensi itu sendiri dimana dikelompokkan dalam kekuatan personal $-I$ am, kemampuan personal-I can, dan faktor dukungan sosial -I have (Grothberg, 1995). I am berarti kekuatan yang berasal dari dalam diri dan merupakan atribut personal yang dihasilkan oleh seseorang yang resilien (kemampuan ini menjadi prediktor dalam resiliensi itu sendiri) dan dapat berhubungan dengan personality (McCrae \& Costa, 1986). Sebagian besar 
kepribadian diukur menggunakan Big Five

Personality Model.

Review ini bertujuan untuk

memberikan gambaran mengenai

hubungan kepribadian dan resiliensi dari

10 jurnal yang dipublikasikan dalam jurnal international mulai tahun 2014-2018.

Review ini dapat digunakan oleh peneliti lain untuk mendukung penelitian yang terkait dengan hubungan kepribadian dan resiliensi.

\section{PROSEDUR REVIEW}

\section{Pencarian Literatur}

Pencarian literatur yang sistematik pada sumber data elektornik menggunakan tema-tema yang relevan yaitu big five personality to resilience. Pencarian artikel melalui google scholar dan sciencedirect secara simultan dan diperoleh 10 artikel dengan tema yang sesuai dengan batas pencarian tahun 2014. Tidak ada batasan tanggal publikasi yang diterapkan. Astrak dari setiap artikel ditinjau dan mengidentifikasi studi yang potensial. Salinan teks dari artikel yang memenuhi sayrat dan potensial selanjutnya di diperiksa dan dipelajari.

\section{Sintesa data}

Beberapa artikel yang telah dikumpulkan diklasifikasikan dalam tabel. Sintesa data dilakukan secara kualitatif berdasarkan informasi dari artikel-artikel yang telah ditulis dalam tabel. Sebagian artikel membahas dalam satu kesatuan model kepribadian dalam 5 faktor, tetapi ada juga jurnal yang mengambil beberapa faktor saja untuk dihubungkan dengan resiliensi.

\section{HASIL DAN PEMBAHASAN}

Setelah mengumpulkan literatur, selanjutnya dilakukan pengkajian pada 10 jurnal hasil penelitian tersebut dengan membuat ringkasan. Maksud dari pembuatan ringkasan ini yaitu agar pembaca mendapatkan gambaran 
mengenai isi dari jurnal penelitian yang

diriview. Selanjutnya dilakukan

pembahasan mengenai kajian yang ada

pada ringkasan tersebut.

Berdasarkan 10 hasil penelitian yang sudah diringkas dalam tabel ringkasan karakteristik di atas, selanjutnya akan dilakukan pembahasan supaya bisa dipergunakan dalam penelitian di Indonesia. Pembahasan ini akan dibagi dalam beberapa sub pembahasan, yaitu berdasarkan karakteristik subjek penelitian, penggunaan alat ukur, dan peran prediktor personality dalam menentukan resiliensi.

Tabel 1. Ringkasan Karakteristik Hasil Penelitian

\begin{tabular}{|c|c|c|c|c|c|}
\hline \multirow[t]{2}{*}{ Peneliti \& Tahun } & \multicolumn{2}{|r|}{ Subjek } & \multicolumn{2}{|c|}{ Variabel } & \multirow[t]{2}{*}{ Alat Ukur } \\
\hline & Jumlah & Karakteristik & Prediktor & Kriterion & \\
\hline $\begin{array}{l}\text { Wei Lu, } \\
\text { Zhenhong Wang, } \\
\text { Ya Liu, Hui } \\
\text { Zhang. (2014) }\end{array}$ & 289 & $\begin{array}{l}\text { Mahasiswa di } \\
\text { Northwestern, China. } \\
42 \text { laki-laki, } 247 \\
\text { perempuan } \\
\text { Rata-rata usia } 20 \\
\text { tahun }\end{array}$ & $\begin{array}{l}\text { Extraversion } \\
\text { dan } \\
\text { Neuroticism }\end{array}$ & Resiliensi & $\begin{array}{l}\text { NEO-FFI } \\
\text { personality } \\
\text { CD-RISC resiliensi }\end{array}$ \\
\hline $\begin{array}{l}\text { Angeliki } \\
\text { Lazaridou, } \\
\text { Apostolia } \\
(2014)\end{array}$ & 109 & $\begin{array}{l}\text { Kepala Sekolah } \\
\text { Dasar } \\
53 \text { perempuan } \\
56 \text { laki-laki }\end{array}$ & $\begin{array}{l}\text { Big Five } \\
\text { Personality }\end{array}$ & Resiliensi & $\begin{array}{l}\text { BFI personality } \\
\text { Leader Resilience } \\
\text { Profile }\end{array}$ \\
\hline $\begin{array}{l}\text { Maria de Ias Olas } \\
\text { Palma-Garcia dan } \\
\text { Isabel } \\
\text { Hombrados- } \\
\text { Mendieta. (2014) }\end{array}$ & 479 & $\begin{array}{l}175 \text { mahasiswa } \\
\text { tingkat } 3 \text { yang } \\
\text { sekaligus sebagai } \\
\text { pekerja sosial. } \\
304 \text { profesional } \\
\text { sebagai pekerja } \\
\text { sosial. } \\
\text { Di Provinsi Malaga, } \\
\text { Spanyol }\end{array}$ & $\begin{array}{l}\text { Personality } \\
\text { Trait }\end{array}$ & Resiliensi & $\begin{array}{l}\text { the big five factor } \\
\text { model } \\
\text { resilience by } \\
\text { Grotberg }\end{array}$ \\
\hline $\begin{array}{l}\text { Meng Shi, Li Liu, } \\
\text { Zi Yue Wang, Lie } \\
\text { Wang. (2015) }\end{array}$ & 2925 & $\begin{array}{l}\text { mahasiswa kesehatan } \\
\text { dari } 4 \text { perguruan } \\
\text { tinggi yang berbeda } \\
\text { di Liaoning, China }\end{array}$ & $\begin{array}{l}\text { Big Five } \\
\text { Personality }\end{array}$ & Resiliensi & $\begin{array}{l}\text { BFI personality } \\
\text { RS-14 resiliensi }\end{array}$ \\
\hline $\begin{array}{l}\text { Nina Sarubin, } \\
\text { Martin Wolf,..., } \\
\text { Frank Padberg } \\
(2015)\end{array}$ & 201 & $\begin{array}{l}107 \text { perempuan. } \\
\text { Subjek yang sehat. }\end{array}$ & $\begin{array}{l}\text { Extraversion } \\
\text { dan } \\
\text { Neuroticism }\end{array}$ & Resiliensi & $\begin{array}{l}\text { NEO-FFI } \\
\text { personality } \\
\text { CD-RISC resiliensi }\end{array}$ \\
\hline $\begin{array}{l}\text { Gholam } \\
\text { E.Fouman, Javad } \\
\text { Salehi, Maryam } \\
\text { Babakhani. } \\
(2015)\end{array}$ & 388 & $\begin{array}{l}\text { Ibu rumah tangga dan } \\
\text { wanita yang bekerja } \\
\text { di Tehran }\end{array}$ & $\begin{array}{l}\text { Personality } \\
\text { trait }\end{array}$ & Resiliensi & $\begin{array}{l}\text { NEO-FFI } \\
\text { personality } \\
\text { CD-RISC resiliensi }\end{array}$ \\
\hline
\end{tabular}




\begin{tabular}{|c|c|c|c|c|c|}
\hline \multirow[t]{2}{*}{ Peneliti \& Tahun } & \multicolumn{2}{|r|}{ Subjek } & \multicolumn{2}{|c|}{ Variabel } & \multirow[t]{2}{*}{ Alat Ukur } \\
\hline & Jumlah & Karakteristik & Prediktor & Kriterion & \\
\hline $\begin{array}{l}\text { Jing Jie, Jie Du. } \\
(2015)\end{array}$ & 110 & $\begin{array}{l}\text { Mahasiswa S1 Univ. } \\
\text { Hainan. } \\
44 \text { Laki-laki } \\
66 \text { perempuan } \\
\text { Usia } 18-23 \text { tahun } \\
\text { Kategori remaja }\end{array}$ & $\begin{array}{l}\text { Conscien- } \\
\text { tiousness }\end{array}$ & Resiliensi & $\begin{array}{l}\text { Neo-FFI } \\
\text { personality } \\
\text { resilience scale for } \\
\text { chinese adolescents }\end{array}$ \\
\hline $\begin{array}{l}\text { Hsiu-Fen Hsieh; } \\
\text { RN, Shu-Chen } \\
\text { Chang; } \\
\text { RN\&Hsiu-Hung } \\
\text { Wang } \\
(2016)\end{array}$ & 230 & $\begin{array}{l}\text { Perawat dengan } \\
\text { kriteria (1) bekerja di } \\
\text { ruang gawat darurat } \\
\text { atau bagian psikiatri; } \\
\text { (2) telah bekerja lebih } \\
\text { dari } 12 \text { bulan }\end{array}$ & Personality & Resiliensi & $\begin{array}{l}\text { EPQ } \\
\text { personality Eysenck } \\
\text { RS } \\
\text { resiliensi }\end{array}$ \\
\hline $\begin{array}{l}\text { Shuhei Iimura \& } \\
\text { Kanako Taku. } \\
(2017)\end{array}$ & 310 & $\begin{array}{l}\text { Siswa menengah } \\
\text { pertama. } \\
155 \text { perempuan } \\
\text { Usia } 14-15 \text { th }\end{array}$ & $\begin{array}{l}\text { Big Five } \\
\text { Personality }\end{array}$ & Resiliensi & $\begin{array}{l}\text { TIPI-J } \\
\text { Personality } \\
\text { BRS-J resiliensi }\end{array}$ \\
\hline $\begin{array}{l}\text { Beatrice Adriana } \\
\text { Balgiu } \\
(2017)\end{array}$ & 192 & $\begin{array}{l}\text { Mahasiswa teknik, } \\
\text { Univ. Politeknik } \\
\text { Bucharest. } \\
\text { Usia } 19-29 \text { th } \\
114 \text { laki-laki } \\
78 \text { perempuan }\end{array}$ & $\begin{array}{l}\text { Big Five } \\
\text { Personality }\end{array}$ & Resiliensi & $\begin{array}{l}\text { BFI-10 } \\
\text { Personality } \\
\text { BRS resiliensi }\end{array}$ \\
\hline
\end{tabular}

\section{Karakteristik Subjek Penelitian}

Karakteristik subjek bervariasi yang dapat dikategorikan dalam variasi pekerjaan, gender, usia, dan asal daerah penelitian dilakukan. Dari pekerjaan, variasi subjek mulai dari siswa sekolah menengah pertama (Iimura \& Taku, 2017), mahasiswa (Lü, Wang, Liu, \& Zhang, 2014), mahasiswa kesehatan (Shi, Liu, Wang, \& Wang, 2015), mahasiswa teknik (Balgiu, 2017), mahasiswa sekaligus pekerja sosial (Garcia \& Mendieta, 2014), kepala sekolah
(Lazaridou \& Beka, 2014), perawat (Hsieh, Chang, \& Hung, 2016), ibu rumah tangga dan wanita yang bekerja (Fouman, Salehi, \& Babakhani, 2015). Masingmasing jenis pekerjaan yang dikerjakan subjek memberikan stressor tersendiri. Dalam perjalanannya setiap orang akan menjalani masa-masa sulit dalam hidupnya, termasuk dalam pekerjaannya. Stressor yang ada pada siswa menengah pertama tentu berbeda dengan stressor yang ada pada mahasiswa, kepala sekolah, perawat ataupun perempuan yang bekerja. 
Untuk itulah dibutuhkan kemampuan untuk bisa bertahan dari masa-masa sulit tersebut.

Variasi lainnya yaitu berdasarkan usia. Pada ringkasan ini subjek termuda yaitu berada pada usia 14-15 tahun yang masih dalam kategori remaja (Iimura \& Taku, 2017). Selain itu beberapa studi lain menggunakan rentang usia remaja hingga dewasa awal (Balgiu, 2017; Shi, Liu, Wang, \& Wang, 2015; Jie \& Du, 2015; Lü, Wang, Liu, \& Zhang, 2014; Garcia \& Mendieta, 2014), serta usia dewasa (Hsieh, Chang, \& Hung, 2016) (Fouman, Salehi, \& Babakhani, 2015; Sarubin, et al., 2015; Lazaridou \& Beka, 2014). Selain itu, beberapa studi juga dilakukan pada berbagai daerah seperti China, Spanyol, Yunani, Tehran. Tentunya perbedaan daerah ini memiliki kebudayaan yang berbeda sehingga dapat mempengaruhi kepribadiaan sese-orang.

\section{Alat Ukur yang Digunakan untuk Kepribadian dan Resiliensi}

Alat ukur yang digunakan untuk mengukur kepribadian maupun resiliensi cenderung berbeda. Akan tetapi beberapa menggunakan alat ukur yang sama. Untuk kepribadian banyak yang menggunakan NEO-FFFI (Neo-Five Factor Inventory). Alat ukur ini dikembangkan oleh Costa dan McCrae yang terdiri atas 60 aitem dengan 12 aitem pada masing-masing faktor (Costa \& McCrae, 1992). Untuk penggunaan NEO-FFI pada subjek di China, maka peneliti menggunakan NEOFFI yang sudah diterjemahkan. Selain itu ada juga yang menggunakan alat ukur BFI (Big Five Inventory). Ada yang menggunakan versi BFI-10 (Rammstedt \& John, 2007), dan ada juga yang menggunakan versi 44 item (John \& Srivastava, 1999). Selain itu ada juga yang menggunakan EPQ (Eysenck Personality Questionnaire) yang terdiri atas 25 aitem (Eysenck \& S. B. G. Eysenck, 1975), 
selanjutnya pada subjek di China menggunakan EPQ yang sudah diterjemahkan dalam bahasa China. Ada pula yang menggunakan TIPI-J (Ten-Item Personality Inventory-Japanese), yaitu terdiri 10 aitem yang sudah diadaptasi dalam bahasa Jepang (Iimura \& Taku, 2017).

Alat ukur yang digunakan untuk mengukur resiliensi juga berbeda-beda. Sebagian besar menggunakan CD-RISC (Conor-Davidson Resilience Scale) yang terdiri atas 25 aitem (Conor \& Davidson, 2003). Selain itu ada juga yang menggunakan RS-14 (Resilience Scale14) yang terdiri atas 14 aitem (Wagnild \& Young, 1993). Selain itu ada juga yang menggunakan BRS (Brief Resilience Scale) yang terdiri atas 6 aitem (Smith, et al., 2008). Beberapa penelitian yang dilakukan di China menggunakan alat ukur resiliensi yang sudah diterjemahkan dalam bahasa China.
Peran Prediktor Personality dalam Menentukan Resiliensi

Berdasarkan jurnal-jurnal yang telah diringkas, extraversion secara konsisten berkorelasi positif dengan resiliensi. Hal ini berarti seseorang semakin tinggi extraversion maka semakin tinggi pula resiliensi. Sebaliknya neuroticism berkorelasi negatif dengan resiliensi. Hal ini berarti semakin tinggi neuroticism seseorang maka akan semakin rendah resiliensi yang dimilikinya. Sedangkan untuk tipe kepribadian yang lain, dari 10 jurnal yang diriviu menunjukkan tidak semua menyatakan hubungan yang konsisten seperti extraversion dan neuroticism.

Extraversion secara konsiten menunjukkan korelasi positif terhadap resiliensi. Sifat yang dimiliki seorang extravert seperti mudah bersosialisasi membantu mereka untuk berusaha bertahan dalam masa sulitnya karena akan banyak teman-teman yang akan 
membantunya atupun dirinya sendiri yang akan tergerak untuk meminta bantuan orang lain untuk menghadapi permasalahannya (Schultz \& Schultz, 2009). Seorang yang extravert tidak akan segan untuk membagi penderitaan dan kesusahannya pada orang lain, sehingga akan meringankan beban secara psikisnya. Sifat seorang extravert yang hangat ini akan mendorong orang lain menjadi tergerak untuk membantunya saat seorang extravert mengalami kesusahan.

Pada penelitian Lü, Wang, Liu, \& Zhang (2014), resiliensi berperan sebagai mediasi antara extraversion dengan kebahagiaan (hubungan positif). Hal ini berarti bahwa seseorang dengan kepribadian extraversion memiliki resiliensi yang lebih tinggi. Selanjutnya Lü, Wang, Liu, \& Zhang menjelaskan bahwa resiliensi ini menjadi faktor protektif untuk membantu seseorang beradaptasi dengan respon-respon untuk mengubah lingkungannya dan secara efektif dapat bangkit kembali dari pengalaman emosi-emosi negatif sehingga dapat meningkatkan kebahagiaan dan positive affect yang tinggi.

Pada studi lainnya yang membandingkan kepribadian pada mahasiswa yang sekaligus sebagai pekerja sosial dan seorang pekerja sosial (secara profesi) menunjukkan bahwa extraversion yang tinggi memberikan pengaruh pada resiliensi baik pada mahasiswa sekaligus berprofesi sebagai pekerja sosial maupun pekerja sosial secara profesional (Garcia \& Mendieta, 2014). Selanjutnya Garcia dan Medieta menjelaskan bahwa extraversion memiliki pengaruh yang paling besar diantara tipe kepribadian lain. Level extraversion yang tinggi (diikuti rendahnya neuroticism) dapat memberikan pengaruh positif pada komponen resiliensi yaitu self-acceptance. Pekerja sosial dihadapkan dengan situasi yang sulit secara terus menerus yang menuntut mereka memiliki keterampilan 
pemecahan masalah yang tinggi, mahasiswa pada tahun ketiga. Mahasiswa pengembangan trait ini berhubungan yang sekaligus sebagai pekerja sosial ini dengan resiliensi, -emosi positif, keuletan menjalankan peran sosial yang beganda, dalam budaya dan pengetahuan, dituntut untuk bisa menyesuaikan dengan keramahan, keperca-yaan diri secara berbagai permasalahan yang interpersonal- dapat meningktkan diahadapinya.

kemampuan untuk mengatasi situasi yang

Dari studi itu dapat dilihat bahwa sulit (Garcia \& Mendieta, 2014). semakin tinggi extraversion yang ada pada Pengembangan resiliensi pada pekerja mahasiswa berkorelasi resiliensinya yang sosial secara positif dengan mengelola juga semakin tinggi. Resiliensi mahasiswa kesulitan, kemudian menuntun pada ini akan berbeda jika dibandingkan dengan peningkatan kompetensi pada seorang pekerja sosial (secara profesionalisme saat dihadapkan dengan profesional).

situasi-situasi yang penuh dengan tekanan

Pada studi yang dilakukan oleh (Menezes de Lucena, Fernandez, Sarubin, dkk. (2015) menunjukkan bahwa Hernandez, Ramos, \& Contador, 2006). extraversion berfungsi sebagai mediator Baik pada mahasiswa yang sekaligus antara pengalaman hidup yang positif sebagai pekerja sosial maupun pada dengan resiliensi. Studi ini menunjukkan pekerja sosial yang profesional, bahwa semakin positif pengalaman hidup kepribadian berhubungan dengan yang pada seseorang yang extraversion, tingginya resiliensi. Selanjutnya Garcia \& maka akan semakin meningkatkan Mendieta menyebutkan bahwa hubungan resiliensinya. Studi ini dilakukan pada yang paling kuat antara peribadian, salah kepala sekolah dasar dimana extraversion satunya extraversion terjadi pada menjadi prediktor yang menentukan 
resiliensi denga ditandai dengan meningkatnya personal efficacy dan physical well-being (Lazaridou \& Beka, 2014).

Pada tipe kepribadian lain menunjukkan bahwa neuroticism secara konsisten berkorelasi negatif dengan resiliensi. Semakin neurotic seseorang (memiliki neuroticism yang tinggi) maka semakin rendah resiliensi yang dimilikinya (Hsieh, Chang, \& Hung, 2016). Seseorang yang neurotic memiliki sifat yang mudah cemas dan merasa tidak aman (Schultz \& Schultz, 2009). Hsieh, Chang \& Hang selanjutnya menjelaskan bahwa orang dengan kepribadiaan neuroticism memiliki emosi negatif. Hal ini membuat kurang bisa bertahan dalam kondisi sulit, ataupun harus bangkit dari masa-masa sulitnya. Seseorang neuroticism akan cenderung memandang hidupnya dengan negatif, sehingga memiliki resiliensi yang rendah (dibandingkan dengan seseorang yang berkepribadian extraversion).

Neuroticism pada seseorang juga dapat mendorong untuk memiliki afek yang negatif. Seperti studi yang dilakukan oleh Lü, Wang, Liu, \& Zhang (2014) menunjukkan bahwa neuroticism berkorelasi secara postif dengan negattive affect dan berkorelasi negatif dengan happiness. Selanjutnya dijelaskan bahwa seseorang yang memiliki kepribadian neurotic akan mudah cemas dan tegang dalam setiap peristiwa dalam hidupnya, kemudian hal ini akan mendorong munculnya afek negatif dalam diri. Jika hal-hal negatif terus dipupuk maka seseorang hanya akan memikirkan tentang peristiwa negatif dan membuat hidupnya menjadi tidak tenang. Untuk itulah bisa dijelaskan bahwa seseorang yang memiliki kepribadian neuroticism cenderung kurang bahagia dalam hidupnya. 
Pada subjek perempuan dan lakilaki terdapat kecenderungan faktor kepribadian tertentu dalam memprediksi resiliensi. Perempuan cenderung memiliki neuroticism yang lebih tinggi daripada laki-laki, dan lak-laki cenderung memiliki extraversion yang lebih tinggi daripada perempuan (Iimura \& Taku, 2017). Hal ini menunjukkan bahwa perempuan cenderung untuk cemas dan khawatir ketika dihadapkan dalam permasalahan atau kondisi yang sulit. Sebaliknya, lakilaki cenderung berusaha bersosialisasi dengan orang lain untuk menghadapi permasalahannya. Selanjutnya Iimura \& Taku (2017) menyebutkan bahwa lakilaki memiliki emotional stability yang lebih tinggi daripada perempuan.

\section{Berbeda dengan kepribadian} extraversion maupun neuroticim yang konsisten dalam hasil penelitian pada beberapa jurnal, faktor kepribadian lain conscienstiousness, agreeableness, dan openess menunjukkan hasil yang belum konsisten pada beberapa penelitian. Ada beberapa penelitian yang melakukan analisis terhadap ketiga faktor ini secara parsial, ada juga yang tidak melakukannya.

Pada penelitian yang menganalisis hubungan agreableness dengan resiliensi, sebagian besar menunjukkan bahwa agreeableness berkorelasi dengan resiliensi. Agreebleness memiliki hubungan yang positif dengan resiliensi pada remaja -di Jepang- (Iimura \& Taku, 2017), yang berarti bahwa semakin agreeable seseorang maka semakin resilien. Seseorang yang memiliki kepribadian agreeableness memiliki sifat yang baik hati, berhati lembut, dan dapat dipercaya cenderung lebih disukai oleh orang lain (Schultz \& Schultz, 2009). Seseorang yang cenderung mudah memperoleh dukungan secara sosial karena kebaikannya itu. Dengan dukungan secara sosial, seseorang yang memiliki kepribadian agreeableness dapat lebih 
resilien ketika dihadapkan dengan kondisi yang buruk (Hsieh, Chang, \& Hung, 2016).

Secara umum agreeableness berhubungan dengan resiliensi. Penelitian lain mencoba untuk menganalisis hubungan agreeableness dengan masingmasing dimensi dari resiliensi -pada kepala sekolah. Hasil menunjukkan bahwa agreebleaness memiliki hubungan negatif dengan support base, personal value, spiritual wellbeing sebagai dimensi dari resiliensi (Lazaridou \& Beka, 2014). Penelitian lainnya justru menyebutkan bahwa agreebleness tidak memiliki hubungan dengan resiliensi -pada ibu rumah tangga dan ibu yang bekerja (Fouman, Salehi, \& Babakhani, 2015).

\section{Kepribadian conscientious-ness}

secara umum memiliki hubungan dengan resiliensi. Hubungan keduanya yaitu secara positif, yang berarti semakin conscienstiousness seseorang maka akan semakin resilien (Shi, Liu, Wang, \&
Wang).

Seseorang

yang

conscienstiousness memiliki sifat peduli dan pekerja keras (Schultz \& Schultz, 2009). Dengan kepedulian pada masamasa sulit yang sedang dialaminya, orang yang conscienstiousness akan berusaha keras untuk mengatasi kesulitannya itu dan bangkit. Orang yang conscienstiousness akan membuat rencana dan mereka lebih menyadari tentang kondisi dirinya, yang kemudian akan menuntun mereka untuk lebih resilien (Iimura \& Taku, 2017). Resiliensi akan memediasi conscienstiousness dengan kepuasan hidup (Jie \& Du, 2015). Lebih lanjut dijelaskan bahwa seseorang yang memiliki conscienstiousness jika terus berlatih untuk menjadi lebih resilien, maka kepuasan hidupnya juga semakin meningkat.

Selanjutnya tipe kepribadian openess, sebagian besar jurnal menyebutkan openess memiliki hubungan dengan resiliensi. Seseorang yang openess 
cenderung memiliki sifat yang kreatif, berani, dan tidak tergantung (Schultz \& Schultz, 2009). Hal ini yang memudahkan mereka untuk berani melakukan alternatifalternatif penyelesaian dari kondisi buruknya. Openess bersama tipe kepribadian lain seperti extraversion dan agreableness menunjukkan hubungan yang positif dengan resiliensi, dimana semakin tinggi openess yang dimiliki seseorang maka semakin tinggi pula resiliensinya (Garcia \& Mendieta, 2014). Seperti studi yang dilakukan oleh Garcia \& Mendieta (2014) yang meneliti pada kelompok mahasiswa sekaligus pekerja sosial dan pekerja sosial secara profesional, menunjukkan bahwa mahasiswa lebih openess dibandingkan yang profesional dan openess ini dapat meningkatkan resiliensi, dengan catatan bahwa neuroticism yang mereka miliki cenderung rendah.

Penelitian lain juga menunjukkan hubungan antara openess dengan resiliensi, dimana resiliensi berperan sebagai mediator untuk menurunkan kecemasan pada seorang yang openess (Garcia \& Mendieta, 2014). Orang yang openess cenderung untuk kreatif dan berpikiran terbuka terhadap suatu hal (Schultz \& Schultz, 2009), sehingga hal itu dapat mendorong seorang openess memiliki kecemasan yang rendah. Seorang openess memiliki keyakinan dan keberanian untuk mengatasi segala permasalahannya sehingga mereka lebih cenderung bertahan atau resilien. Pada penelitian lain yang membandingkan kepribadian pada laki-laki dan perempuan, hasilnya menunjukkan bahwa laki-laki cenderung memiliki openess yang lebih tinggi daripada perempuan dalam hubungannya dalam menentukan resiliensi (Iimura \& Taku, 2017). Selanjutnya Iimura \& Taku menyebutkan bahwa lakilaki cenderung memiliki pemikiran yang terbuka ketika meghadapi masalah dibandingkan perempuan, sehingga laki- 
laki yang memiliki yang memiliki pada seseorang maka semakin tinggi pula kepribadian openess lebih resilien. Akan resiliensi. Sebaliknya neuroticism tetapi hasil yang berlawanan ditunjukkan berkorelasi negatif dengan resiliensi. Hal bahwa openess tidak memiliki hubungan ini berarti semakin tinggi neuroticism secara signifikan dengan resiliensi -pada seseorang maka akan semakin rendah primary school in Greek (Lazaridou \& resiliensi yang dimilikinya. Sedangkan Beka, 2014). Tidak adanya hubungan untuk tipe kepribadian yang lain tidak antara tipe kepribadian openess dengan secara konsisten menyatakan korelasinya kompenen resiliensi yaitu leadership dengan resiliensi.

effectiveness. Meskipun tidak ada hubungan, selanjutnya Lazaridou \& Beka menjelaskan bahwa openess to expereinece pada level yang tinggi dapat menuntun seseorang untuk memiliki imajinasi, kecerdikan, reativitas, dan keinginan untuk bereksperimen yang kesemua itu akan berkontribusi pada efektivitas dalam kepemimpinan di sekolah.

\section{KESIMPULAN}

\section{Secara konsisten extraversion} berkorelasi positif dengan resiliensi. Hal ini berarti semakin tinggi extraversion

\section{SARAN}

Pada penelitian selanjutnya dapat mengembangkan hasil systematic review semacam ini menjadi jurnal meta-analisis, sehingga pengkajiannya dilakukan lebih mendalam. Dilihat dari hubungan beberapa faktor personality kepada resiliensi, faktor extraversion dan neuroticism memiliki hubungan yang cenderung stabil, sehingga penelitian selanjutnya dapat meneliti hubungan ketiga faktor personality lainnya terhadap resiliensi yang masih cenderung belum stabil. 


\section{DISKUSI}

Berbagai tipe kepribadian

memiliki hubungan dengan resiliensi.

Dimana resiliensi membantu seseorang untuk dapat bertahan dalam kondisi sulit dan bangkit kembali (Conor \& Davidson, 2003). Resiliensi yang terjadi pada seseorang juga bervariasi dalam berbagai tipe kepribadian. Seperti pada seseorang yang memiliki kepribadian extraversion yang memiliki sifat yang terbuka terhadap lingkungannya sehingga membuatnya lebih mudah untuk beradaptasi dengan perubahan lingkungannya, berbeda dengan seseorang dengan tipe kepribadian neuroticism yang cenderng memiliki kecemasan dan negative affect yang mendorongnya lebih sulit untuk mengatasi kondisi sulit.

Melalui review jurnal ini dapat membandingkan bagaimana satu tipe kepribadian dan tipe lainnya memiliki hubungan dalam proses seseorang beradaptasi dengan lingkungannya. Hal ini menjadi penting untuk mengenal untuk mengidentifikasi tipe kepribadian apa yang dimiliki karena dapat memungkinakan perilaku yang tepat untuk menghadapi sebuah situasi yang sulit.

Penyajian review yang menyajikan berbagai jurnal dari berbagai daerah dan latar belakang usia maupu profesi, dapat menjadi sebuah pertimbangan bahwa tipe kepribadian dan kemampuan seseorang untuk beradaptasi bisa saja berbeda-beda untuk tiap daerah di seluruh belahan dunia ini. hal ini bisa diprediksi melalui latar belakang seseorang. Lingkungan seseorang tumbuh memungkinkan untuk berpengaruh pada cara seseorang untuk memandang hidupnya ataupun menentukan perilaku yang tepat untuk merespon suatu hal.

Akan tetapi model review ini masih memiliki kekurangan. Penyajian review ini masih bersifat deskriptif dan hanya menjabarkan bagaimana hasil temuan dari beberapa literatur. Pada 
model review ini tidak dilakukan analisis yang lebih mendalam terkait hasil-hasil penelitian, sehingga kedepannya model review ini dapat dikembangkan menjadi model meta-analisis dengan perbandingan jurnal yang lebih banyak dan luas. Selain itu, model hubungan variabel juga dapat dikembangkan dalam berbagai variasi, tidak hanya hubungan keribadian dan resiliensi tetapi juga ada variabel lain yang memungkinkan bagaimana kepribadian dapat menjelaskan resiliensi -misalkan self-acceptance-.

\section{DAFTAR PUSTAKA}

Balgiu, B. A. (2017). Self-esteem, Personality and Resilience. Study of a Students Emerging Adults Group. Journal of Educational Sciences \& Psychology.

Bluth, K., Campo, R. A., Futch, W. S., \& Gaylord, S. A. (2016). Age and Gender Differences in The Associations on Self-Compassion and Emotional Well-Being in a Large Adolenceent Sample. Journal of Youth and Adolescence, 1-14. doi:http://dx.doi.org/10.1007/s109 64-016-0567-2

Buikstra, E., Ross, H., King, C. A., BAker, P. G., Hegney, D., McLachlan, K., \& Rogers-Clark, C. (2010). The components of resilience: Perceptions of an Australian rural community. Journal of Community Psychology, 38(8), 975-91.

Conor, K. M., \& Davidson, J. R. (2003). Development of A New Resilience Scale: The Conor-Davidson Resilience (CD-RISC). Depression and Anxiety 18, 76-82.

Costa, P., \& McCrae, R. R. (1992). Resived NEO personality inventory and NEO five factor inventory professional manual. Odessa, FL: Psychological Assessment Resources.

Davydov, D. M., Stewart, R., \& Chaudieu, I. (2010). Resilience and mental health. Clinical Psychology Review 30(5), 579-495.

Eysenck, H. J., \& S. B. G. Eysenck. (1975). Manual for the Eysenck Personality Questionnaire. Londo, UK: Hodder dan Stoughton.

Fouman, G. E., Salehi, J., \& Babakhani, M. (2015). The Relationship 
Between Resilience and

Personality Traits in Women.

JOurnal of Educational and

Management Studies.

Garcia, M. O., \& Mendieta, I. H. (2014).

Resilience and Personality in

Social Work Students and Social

Workers. International Social

Work.

Grothberg, E. H. (1995). The international resilience project: Research, application, and policy. International Symposium on Stress and Violence, Lisbon, Portugal.

Hsieh, H.-F., Chang, S.-C., \& Hung, R. (2016). The Relationships Among Personality, Social Support, and Resilience of Abused Nurses at Emergency Rooms and sychiatric Wards. Women \& Health.

Iimura, S., \& Taku, K. (2017). Gender Differences in Relationship Between Resilience and Big Five Personality in Japanese Adolescents. Psychological Reports.

Jie, J., \& Du, J. (2015). Resilience as a Mediator Between Conscientiousness and Life Satisfaction Among Chinese
College Students. International Conference on Social Science and Higher Education.

John, O. P., \& Srivastava, S. (1999). The Big Five trait taxonomy: History, measurement, and theoretical perspectives. Dalam L. A. Pervin, \& O. P. John, Handboo of ersonality (hal. 102-138). New York: Guilford Press.

Lazaridou, A., \& Beka, A. (2014). Personality and Resilience Characteristics of Greek Primary School Principals. Educational Management Administration \& Leadership.

Leon, M. R., \& Halbesleben, J. R. (2014). Building resilience to improve employee wellbeing. Dalam A. M. Rossi, J. A. Meurs, \& P. L. Perrewe, Improving employee health and wellbeing (hal. 65). USA: Information Age Publishing. Liu, Y., Wang, Z., Zhou, C., \& Li, T. (2014). Affect and self-esteem as mediators between trait resilience and psychological adjustment. Personality and Individual Differences, 92-97. 
Lü, W., Wang, Z., Liu, Y., \& Zhang, H. (2014). Resilience as A Mediator Between Extraversion, Neuroticism, and Happiness, PA, NA. Personality and Individual Differences 63, 128-133.

McCrae, R. R., \& Costa, P. T. (1986). Personality, coping, and doping effectiveness in an adult sample. Journal of Personality, 54, 385405.

Menezes de Lucena, V. A., Fernandez, B., Hernandez, L., Ramos, F., \& Contador, I. (2006). Resiliencia y el modelo Burnout-Engagement en cuidadores females de ancianos. Psicothema, 18(4).

Oshio, A., Taku, K., Hirano, M., \& Saeed, G. (2018). Resilience and Big Five personality traits: A meta-analysis. Personality and Individual Differences 127, 54-60.

Rammstedt, B., \& John, O. P. (2007). Measuring personality in one minute or less: A 10-item short version of the Big Five Inventory in English and German. Journal of Research in Personality, 4(1), $203-$ 212.
Reivich, K., \& Shatte, A. (2002). The Resilience Factor, 7 Essential Skill For Overcoming Life's Ineritable Obstacle. New York: Broadway Books.

Sarubin, N., Wolf, M., Giehling, I., Hilbert, S., Naumann, F., Gutt, D., . . Padberg, F. (2015). Neuroticism and extraversion as mediators between positive/negative life events and resilience. Personality and Individual Differences 82, 193198.

Satici, S. A. (2016). Psychological vulnerability, resilience, and subjective well-being: The mediating role hope. Personality and Differences, 68-73.

Schultz, D. P., \& Schultz, S. E. (2009). Theories of Personality, Ninth Edition. Belmont, USA: Wadswoth Cengage Learning.

Shi, M., Liu, L., Wang, Z. Y., \& Wang, L. (2015). The Mediating Role of Resilience in the Relationship between Big Five Personality and Anxiety among Chinese Medical Students: A Cross-Sectional Study. Plos One. 
Sills, L. C., Cohan, S. L., \& Stein, M. B. (2006). Relationship of resilience to personality, coping, and psychiatric sy,toms in young adults. Behaviour Research and Therapy 44, 585-599.

Smith, B. W., Dalen, J., Wiggins, K., Tooley, E., Christopher, P., \& Bernard, J. (2008). The brief resilience scale: assesing the ability to bounce back.

INternational Journal of Behavioral Medicine, 15(3), 194200.

Wagnild, G. M., \& Young, H. M. (1993). Development and psychometric evaluation of the resilience scale. $J$ Nurs Measur, 165-178. 